\title{
Evaluation of Carrageenan, Xanthan Gum and Depolymerized Chitosan Based Coatings for Pineapple Lily Plant Production
}

\author{
Piotr Salachna *(D) and Anna Pietrak (D) \\ Department of Horticulture, West Pomeranian University of Technology, 3 Papieża Pawła VI Str., \\ 71-459 Szczecin, Poland; pa37778@zut.edu.pl \\ * Correspondence: piotr.salachna@zut.edu.pl; Tel.: +48-91-449-6359
}

Citation: Salachna, P.; Pietrak, A. Evaluation of Carrageenan, Xanthan Gum and Depolymerized Chitosan Based Coatings for Pineapple Lily Plant Production. Horticulturae 2021, 7, 19. https://doi.org/10.3390/ horticulturae7020019

Academic Editor: Douglas

D. Archbold

Received: 31 December 2020

Accepted: 27 January 2021

Published: 29 January 2021

Publisher's Note: MDPI stays neutral with regard to jurisdictional claims in published maps and institutional affiliations.

Copyright: (c) 2021 by the authors. Licensee MDPI, Basel, Switzerland. This article is an open access article distributed under the terms and conditions of the Creative Commons Attribution (CC BY) license (https:// creativecommons.org/licenses/by/ $4.0 /)$.

\begin{abstract}
Some natural polysaccharides and their derivatives are used in horticulture to stimulate plant growth. This study investigated the effects of coating bulbs with carrageenan-depolymerized chitosan (C-DCh) or xanthan-depolymerized chitosan (X-DCh) on growth, flowering, and bulb yield as well as physiological and biochemical attributes of pineapple lily (Eucomis autumnalis). The results showed that treatment with C-DCh or X-DCh significantly increased all growth parameters, bulb yield, greenness index, stomatal conductance, total $\mathrm{N}$, total $\mathrm{K}$, and total sugar content of bulbs and accelerated anthesis as compared with untreated bulbs. The positive impact of coatings on plant growth and physiological attributes depended on the type of biopolymer complexes. The X-DCh treatment exhibited the greatest plant height, fresh weight, daughter bulb number, greenness index, stomatal conductance, total N, K, and sugar content. However, this treatment induced a significant decrease in L-ascorbic acid, total polyphenol content and antioxidant activity. Overall, the results of this study indicated high suitability of C-DCh and X-DCh as bulb coatings for pineapple lily plant production.
\end{abstract}

Keywords: biostimulants; polysaccharides; bulb coating; plant enhancement; metabolites

\section{Introduction}

Currently, biostimulants are used to improve growth and development of horticultural plants [1,2]. Biostimulants are a broad group of substances and microorganisms with high biological activity [3-5]. Of particular interest are biodegradable polysaccharides and their depolymerized derivatives exhibiting multi-directional actions in plants [6-10]. Chitosan is one of the best known natural polysaccharides with biostimulatory properties obtained in the process of chitin de-N-acetylation [11,12]. Chitosan and its oligomeric forms have stimulated plant growth and flowering, increased photosynthesis and nutrient uptake, and protected plants against stress [13-16]. Many studies have reported the benefits provided by chitosan on various ornamental plants, such as Begonia $\times$ hiemalis Fotsch [17], Chrysanthemum morifolium Ramat [18], Eucomis bicolor Baker [19], Freesia $\times$ hybrida [20], and Petunia $\times$ atkinsiana D. Don [21]. In practice, chitosan solution is applied as a spray or drench [22-24] as well as hydrogels for coating seeds, but hydrogels from "pure" chitosan have low stability and durability [25]. Moreover, the wider use of chitosan is limited due to its poor water solubility [26]. The application of depolymerized chitosan with low molecular weight and ionic biopolymers in the form of hydrogel coating formed on the surface of plant organs based on polyelectrolyte complexes may be the solution to the problem [27]. This type of coating formed by chitosan and ionic polymers can positively affect plant growth and flowering [28]; however, it is reasonable to conduct broader research, including evaluation of the effectiveness of various biopolymers as coating components [29]. Carrageenans are a family of anionic polymers extracted from red algae used as plant biostimulants $[10,30,31]$. Carrageenans and their breakdown products can stimulate plant productivity and root system development, and enhance net photosynthesis, basal, and secondary metabolisms [32-36]. Among natural biopolymers, xanthan gum, an 
anionic, high-molecular-weight exo-polysaccharide secreted by the bacterium Xanthomonas campestris is also known [37]. Application of xanthan gum can influence plant growth and physiology, content of phenolic compounds, and antioxidant activity [38-40]. Xanthan gum used in micropropagation as an alternative to agar has a positive effect on the regenerative potential of some plants [41], which may indicate its biostimulative action. However, no information is available regarding the effect of xanthan gum as a biostimulant on plant growth and flowering.

Pineapple lily (Eucomis autumnalis (Mill.) Chitt. Asparagaceae) is a prospective bulbous ornamental plant grown in gardens, for cut flowers, and as a potted plant for indoor display [42-44]. The bulbs produce a rosette of smooth leaves and original decorative raceme-type inflorescences with a tuft of leaf-like bracts on top, composed of star-shaped white flowers with a pleasant scent. After flowering, the plants set decorative and durable green capsules. Besides its ornamental use, pineapple lily is one of the most popular plant species in traditional medicine in southern Africa [45]. The extracts of pineapple lily exert multidirectional effects, including antioxidant, anti-inflammatory, bactericidal, fungicidal and cytostatic effects $[45,46]$. The species is threatened with extinction in its natural habitat due to the excessive collection of bulbs for medicinal purposes as well as low vegetative propagation rate [45]. Thus, proper production methods of pineapple lily using various plant biostimulants is needed $[47,48]$.

Previous work [49] reported that oligochitosan and sodium alginate can be successfully used for the preparation of hydrogel coatings for the bulbs of pineapple lily. However, systematic study of the effects of other biopolymers on growth, plant physiological status, and biochemical parameters of pineapple lily remains to be investigated. The current study was aimed to compare the effects of coatings containing hydrogels based on carrageenan or xanthan gum with depolymerized chitosan on the growth characteristics, flowering, bulb yield, physiological parameters, nutrients, L-ascorbic acid, and total polyphenol content, as well as antioxidant activity of pineapple lily. It was hypothesized that a coating treatment with polysaccharides would enhance the growth and bulb production of pineapple lily.

\section{Materials and Methods}

\subsection{Plant Culture and Treatment}

Bulbs of pineapple lily (E. autumnalis) with 12-14 cm circumference were imported from The Netherlands by Ogrodnictwo Wiśniewski Jacek Junior (Góraszka, Poland) and treated for $30 \mathrm{~min}$ in a suspension of $0.7 \%$ Topsin M 500 SC and 1\% Captan 50 WP fungicides. Before planting, the uniform bulbs were coated according to the technology described by Startek et al. [29] in hydrogels based on $1 \%(w / v)$ carrageenan or $1 \%(w / v)$ xanthan gum in which bulbs were dipped for $30 \mathrm{~s}$, and $0.2 \%(w / v)$ depolymerized chitosan in which the bulbs were soaked for $10 \mathrm{~min}$. Control bulbs were soaked in distilled water. Depolymerized chitosan obtained by controlled free radical degradation [28] had a molecular weight of 154, $500 \mathrm{~g} \mathrm{~mol}^{-1}$, the number-average molecular weight of $22,800 \mathrm{~g} \mathrm{~mol}^{-1}$, and deacetylation degree of $85 \%$. Carrageenan-depolymerized chitosan (C-DCh) and xanthan-depolymerized chitosan (X-DCh) were produced. Iota-carrageenan and xanthan gum were purchased from Sigma-Aldrich. Polysaccharides were prepared by solubilization using a magnetic stirrer. Each treatment was replicated four times and each replicate had 10 bulbs.

Coated bulbs were planted in a randomized block design on 15 April 2016 and 13 April 2017 into polyethylene boxes $(60 \times 40 \times 19 \mathrm{~cm})$ filled with peat substrates $(\mathrm{pH}$ 6.3) supplemented with a fertilizer Hydrocomplex $(12 \% \mathrm{~N}, 4.5 \% \mathrm{P}$, and $15 \% \mathrm{~K}$ plus micronutrients; Yara International ASA, Oslo, Norway) at a dose of $3 \mathrm{~g} \mathrm{~L}^{-1}$. Each box contained 10 bulbs. The boxes were transferred to a non-heated tunnel covered with a double layer of plastic located in the area of West Pomeranian University of Technology in Szczecin $\left(53^{\circ} 25^{\prime} \mathrm{N}\right.$, $14^{\circ} 32^{\prime} \mathrm{E} ; 25 \mathrm{~m}$ a.s.1.). Air temperature inside the tunnel was controlled with vents that were opened when the temperature exceeded $20^{\circ} \mathrm{C}$. 


\subsection{Measurement of Growth Parameters}

The number of days to anthesis was recorded. When the first flowers opened in the raceme, plant height, diameter of the plant, and inflorescence length were recorded. At the end of the flowering period, the number of florets in the inflorescence were counted and fresh weight of the excised aboveground part was measured. On 3 October 2016 and 6 October 2017, the plants were removed from boxes, and fresh weight of bulbs per plant and the number of daughter bulbs were determined.

\subsection{Measurement of Physiological Parameters}

At the flowering stage, relative leaf chlorophyll content measurements were performed using a SPAD-502 Chlorophyll Meter (Minolta, Osaka, Japan) and stomatal conductance was assessed with a SC-1 Leaf Porometer (Dekagon Device, Pullwan, WA, USA). SPAD and stomatal conductance measurements were calculated based on four readings of four uniform leaves selected from five plants of each treatment.

\subsection{Total N, P, K, and Total Sugar Content in Bulb Determination}

At the end of the growing season, the bulb samples were collected, dried at $65^{\circ} \mathrm{C}$ for $72 \mathrm{~h}$ and ground. Powdered samples $(2.0 \mathrm{~g})$ were digested in $17 \mathrm{~mL}$ concentrated $96-97 \%$ $\mathrm{H}_{2} \mathrm{SO}_{4}$. The total forms of $\mathrm{N}, \mathrm{P}$, and $\mathrm{K}$ were determined as outlined by Ostrowska [50]. Total $\mathrm{N}$ was determined according to the Kjeldahl method, $\mathrm{P}$ with colorimetric method according to Barton, and $\mathrm{K}$ by flame photometry [50]. The content of total sugar in samples of fresh bulbs was determined following the Luff-Schoorl method [51]. Nutrients and total sugar content were determined using three replicates per treatment.

\subsection{L-Ascorbic Acid, Total Polyphenol Content, and Antioxidant Activity Determination}

At the flowering stage, fully developed leaves were taken for biochemical analyses. Before homogenization, leaves were washed with water to remove soil, cut into slices, and dried in a circulating-air oven $\left(35^{\circ} \mathrm{C} \pm 2{ }^{\circ} \mathrm{C}\right)$. Vitamin $\mathrm{C}$ was determined as L-ascorbic acid by the Tillman's titration method of the reduction of 2.6-dichlorophenolindophenol [52]. The preparation of plant extracts for the determination of the total polyphenol content and antioxidant activities was performed using the method of Wojdyło et al. [53] with some modifications. The sample of leaves was treated with $70 \%$ aqueous methanol $(\mathrm{MeOH})$. Total polyphenol content was analyzed spectrophotometrically using the Folin-Ciocalteu colorimetric method as described by Wojdyło et al. [53]. The absorbance was measured at $760 \mathrm{~nm}$. Antioxidant activity of leaves on DPPH (2,2-diphenyl-1-picrylhydrazyl) radical was determined according to the procedure of Yen and Chen [54], and DPPH inhibition percentage was calculated according to the formula provided by Rossi et al. [55]. All determinations were carried out in three replicates.

\subsection{Statistical Analysis}

Data were normally distributed and passed Levene's test $(\alpha \leq 0.05)$ for homogeneity of variance. Data were statistically analyzed by one-way ANOVA using Statistica ${ }^{\mathrm{TM}}$ Professional 13.3.0 software (TIBCO Statistica, Palo Alto, CA, USA). After checking the goodness of fit of the model, post hoc comparisons were done using the Duncan's Multiple Range Test (DMRT) at $\alpha \leq 0.05$. The results are presented as a mean from two years of the study.

\section{Results}

The effect of coating with carrageenan-depolymerized chitosan (C-DCh) or xanthandepolymerized chitosan (X-DCh) on growth and flowering of pineapple lily is shown in Table 1. The C-DCh and X-DCh applications significantly increased plant height by $8 \%$ and $16 \%$, respectively, plant width by $39 \%$ and $40 \%$, respectively, fresh weight of the aboveground part by $71 \%$ and $95 \%$, respectively, inflorescence length by $32 \%$ and $25 \%$, respectively, and the number of florets by $8 \%$ and $9 \%$, respectively, as well as accelerated flowering by 17 and 13 days, respectively. Statistically significant differences were observed 
between X-DCh and C-DCh treatments. Bulbs coated in X-DCh were taller by 7\% and had a greater fresh weight of the aboveground part by $16 \%$, compared with bulbs coated in C-DCh.

Table 1. Growth and flowering parameters of pineapple lily treated with carrageenan-depolymerized chitosan (C-DCh) or xanthan-depolymerized chitosan (X-DCh).

\begin{tabular}{cccc}
\hline \multirow{2}{*}{ Parameter } & \multicolumn{3}{c}{ Type of Coatings } \\
\cline { 2 - 4 } & Control & C-DCh & X-DCh \\
\hline Plant height $(\mathrm{cm})$ & $32.6 \pm 0.96 \mathrm{c}^{\mathrm{z}}$ & $35.1 \pm 0.59 \mathrm{~b}$ & $37.7 \pm 1.07 \mathrm{a}$ \\
Plant diameter $(\mathrm{cm})$ & $25.7 \pm 1.61 \mathrm{~b}$ & $35.8 \pm 1.86 \mathrm{a}$ & $36.0 \pm 1.17 \mathrm{a}$ \\
Fresh weight of the & $107 \pm 1.91 \mathrm{c}$ & $183 \pm 4.10 \mathrm{~b}$ & $209 \pm 4.07 \mathrm{a}$ \\
aboveground part $(\mathrm{g})$ & $16.5 \pm 1.70 \mathrm{~b}$ & $21.7 \pm 1.19 \mathrm{a}$ & $20.7 \pm 0.72 \mathrm{a}$ \\
Length of inflorescence $(\mathrm{cm})$ & $72.6 \pm 3.39 \mathrm{~b}$ & $78.6 \pm 1.46 \mathrm{a}$ & $79.2 \pm 1.15 \mathrm{a}$ \\
Number of florets & $161 \pm 2.08 \mathrm{a}$ & $144 \pm 3.21 \mathrm{~b}$ & $148 \pm 2.52 \mathrm{~b}$ \\
Days to anthesis & &
\end{tabular}

${ }_{\mathrm{z}}$ Means $( \pm$ SD) followed by the same small letter in the same row did not differ by Duncan's Multiple Range Test at $\alpha \leq 0.05$.

The fresh weight of bulbs, number of daughter bulbs, total N, K, and total sugar content in the pineapple lily bulbs were significantly affected by C-DCh or X-DCh complexes (Table 2). The coating of bulbs with C-DCh and X-DCh enhanced fresh weight of bulbs by $39 \%$ and $61 \%$, respectively, and number of daughter bulbs by $24 \%$ and $48 \%$, respectively. Moreover, the application of C-DCh and X-DCh increased levels of N by $49 \%$ and $54 \%$, respectively, $\mathrm{K}$ by $46 \%$ and $57 \%$, respectively, and total sugar content by $12 \%$ and $17 \%$, respectively, in comparison with the control. The treatment with X-DCh resulted in the greatest fresh weight of bulbs, number of daughter bulbs, and total N, K, and sugar content. Bulb treatment with C-DCh and X-DCh did not affect total P content.

Table 2. Fresh weight of bulbs, number of daughter bulbs, total N, P, K, and total sugar content in bulb of pineapple lily treated with carrageenan-depolymerized chitosan (C-DCh) or xanthandepolymerized chitosan (X-DCh).

\begin{tabular}{cccc}
\hline \multirow{2}{*}{ Parameter } & \multicolumn{3}{c}{ Type of Coatings } \\
\cline { 2 - 4 } & Control & C-DCh & X-DCh \\
\hline Fresh weight of bulbs (g) & $31.0 \pm 1.87 \mathrm{c}^{\mathrm{z}}$ & $43.0 \pm 2.61 \mathrm{~b}$ & $50.0 \pm 4.95 \mathrm{a}$ \\
Number of daughter bulbs & $0.75 \pm 0.15 \mathrm{c}$ & $0.93 \pm 0.07 \mathrm{~b}$ & $1.11 \pm 0.10 \mathrm{a}$ \\
Total N content (\% DW) & $0.39 \pm 0.03 \mathrm{c}$ & $0.58 \pm 0.02 \mathrm{~b}$ & $0.64 \pm 0.02 \mathrm{a}$ \\
Total P content (\% DW) & $0.05 \pm 0.01 \mathrm{a}$ & $0.06 \pm 0.01 \mathrm{a}$ & $0.05 \pm 0.01 \mathrm{a}$ \\
Total K content (\% DW) & $0.44 \pm 0.02 \mathrm{c}$ & $0.64 \pm 0.03 \mathrm{~b}$ & $0.69 \pm 0.02 \mathrm{a}$ \\
Total sugar content $(\%$ FW) & $6.66 \pm 0.39 \mathrm{~b}$ & $7.47 \pm 0.15 \mathrm{a}$ & $7.76 \pm 0.16 \mathrm{a}$ \\
\hline
\end{tabular}

${ }_{\mathrm{z}}$ Means ( $\left.\pm \mathrm{SD}\right)$ followed by the same small letter in the same row did not differ by Duncan's Multiple Range Test (DMRT) at $\alpha \leq 0.05$.

As shown in Figure 1, SPAD chlorophyll meter measurements and stomatal conductance were significantly increased due to C-DCh and X-DCh treatment in comparison to control. The C-DCh increased SPAD and stomatal conductance by $11 \%$ and $55 \%$, and X-DCh by $7 \%$ and $31 \%$, respectively. The SPAD and stomatal conductance of plants treated with X-DCh were 3\% and 19\%, respectively, greater than that of C-DCh treatment.

Figure 2 shows the effects of bulb coatings on the content of L-ascorbic acid and total polyphenols and the antioxidant activity. In comparison with the control the application of C-DCh or X-DCh significantly decreased total polyphenol content by $13 \%$ and $17 \%$, respectively. Furthermore, the application of X-DCh significantly decreased L-ascorbic acid content by $33 \%$ and free DPPH radicals by $56 \%$. The plant L-ascorbic acid content and antioxidant activity showed no statistically significant differences between control and C-DCh treatment. 


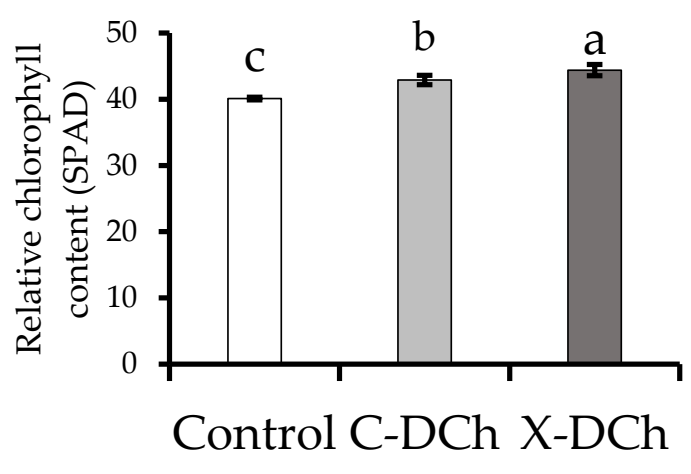

(a)

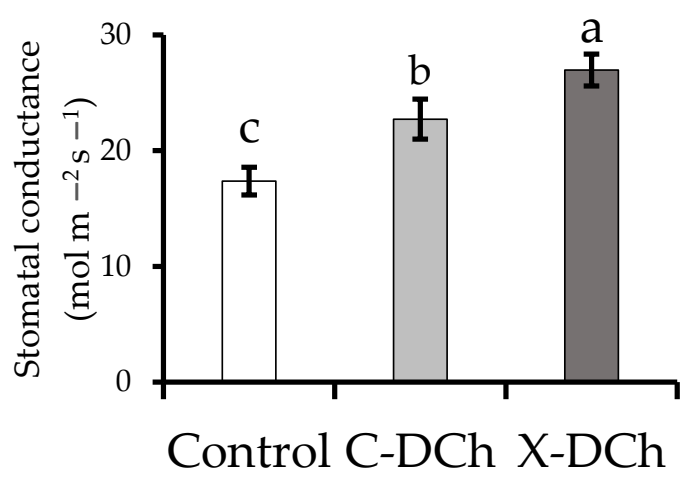

(b)

Figure 1. Relative leaf chlorophyll content (SPAD) (a) and stomatal conductance (b) of pineapple lily treated with carrageenan-depolymerized chitosan (C-DCh) and xanthan-depolymerized chitosan (X-DCh). Data are presented as means $( \pm \mathrm{SD})$ and bars with different letters in each graph are significantly different by Duncan's Multiple Range Test (DMRT) at $\alpha \leq 0.05$.

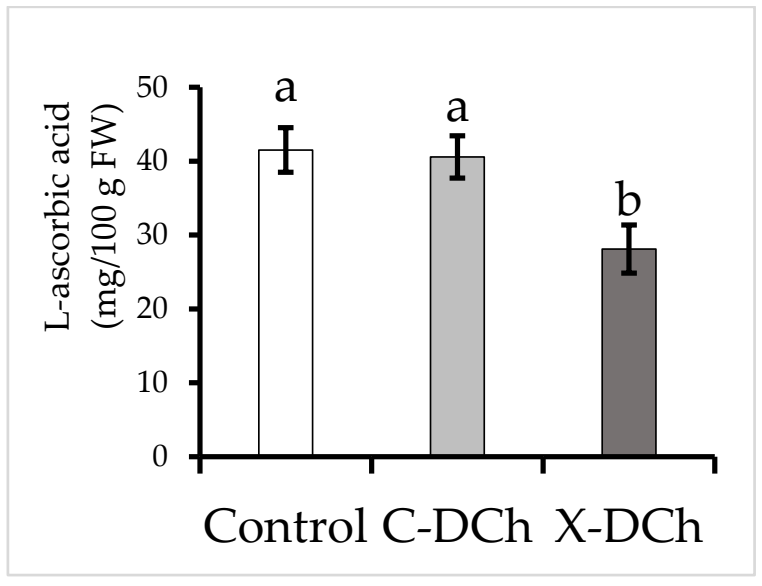

(a)

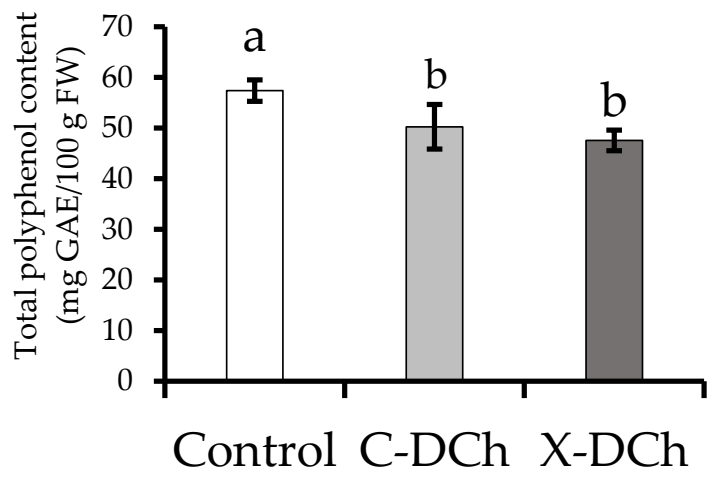

(b)

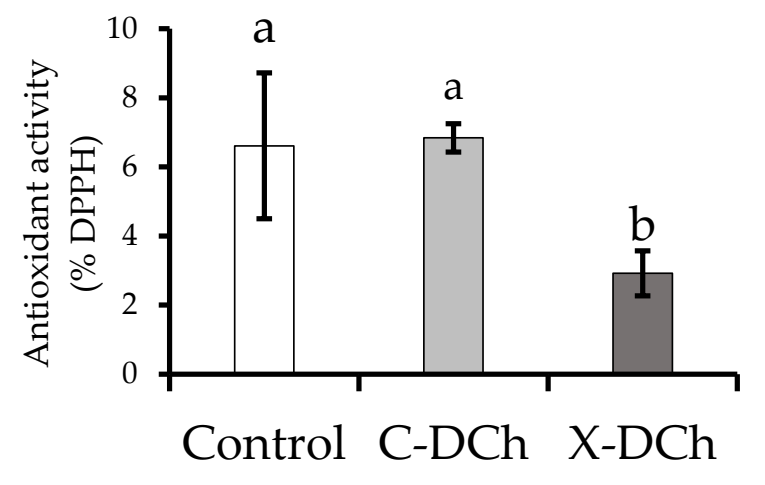

(c)

Figure 2. L-ascorbic acid (a) and total polyphenol content (b) and antioxidant activity (DPPH) (c) of pineapple lily treated with carrageenan-depolymerized chitosan (C-DCh) and xanthan-depolymerized chitosan (X-DCh). Data are presented as means $( \pm \mathrm{SD})$ and bars with different letters in each graph are significantly different by Duncan's Multiple Range Test (DMRT) at $\alpha \leq 0.05$. 


\section{Discussion}

Most studies on the application of biostimulant coatings focus on seeds, while data on coating other plant organs such as bulbs, tubers or rhizomes are far less available [56]. Our study is the first to use two biostimulant complexes, containing depolymerized chitosan and carrageenan $(\mathrm{C}-\mathrm{DCh})$ or xanthan $(\mathrm{X}-\mathrm{DCh})$, for coating pineapple lily bulbs. We found a stimulatory effect of both types of coatings on plant growth and development manifested in accelerated flowering and clearly higher yield of flowers and bulbs. In addition, plants grown out of biostimulant-coated bulbs featured more efficient gas exchange and better nutrient content. Some results of the current study are in agreement with our earlier work [29]. We reported a considerable improvement in plant growth, as assessed by morphological and physiological parameters and nutrient content in E. autumnalis when the bulbs were coated with oligochitosan and sodium alginate, and in Ornithogalum saundersiae Baker when the bulbs were coated with chitooligosaccharide and sodium alginate, carrageenan, gellan gum, or xanthan gum [28,49]. Stimulating effects of the coatings were probably due to the fact that their components enhanced plant tolerance to stresses from the beginning of their development, similar to that noted with seed coating [56]. Chitosan can improve growth and structure of a plant root system by limiting the presence of soil pathogens [11,12]. As a source of carbon for microorganisms, it also indirectly boosts soil microbial activity and thus improves absorption of minerals and water by plant roots [15]. In consequence, plants grow faster and stronger and produce better yield. Carrageenan may act as an elicitor that induces plant defense response against viroids, viruses, bacteria, or fungi, and it also may improve plant growth by controlling numerous metabolic processes including photosynthesis and assimilation of nitrogen and sulfur [10,30,35]. Xanthan gum is also capable of inducing local and systemic resistance against diseases and shows the same efficiency in plant protection against some phytopathogens as fungicides [38,57]. Soil application of xanthan gum may increase root biomass production and plant tolerance to drought and other environmental stresses [40].

The results presented in this paper demonstrated that the positive effects of coating pineapple lily bulbs on plant growth depended on the type of biopolymer complexes. The strongest plant growth stimulation was observed in plants obtained from bulbs treated with X-DCh complex. We assume that joint application of the biostimulants in X-DCh coatings may induce a stronger synergistic effect than C-DCh coating alone. It is commonly known that many biologically active substances change their properties when interacting with other substances [58,59]. Interestingly, the stimulating effect of X-DCh on the growth of the aboveground plant tissues and bulb biomass and the content of $\mathrm{N}, \mathrm{K}$, and total sugars in pineapple lily was accompanied by a clear drop in the levels of L-ascorbic acid and total polyphenols and by reduced antioxidant activity, responses not recorded in plants treated with C-DCh. The inhibitory effect of X-DCh treatment on secondary metabolite production may be a result of a trade-off between the production of plant biomass and secondary metabolism [60]. It is well known that defense and plant growth cannot usually be successfully executed at the same time [61,62]. Another possible interpretation, in line with previously cited research, is that xanthan gum induced a reduction in polyphenol content due to activation of some cellular biochemical mechanisms involved in plant resistance [57]. Still, further studies are necessary to validate either of these hypotheses.

\section{Conclusions}

The biostimulant complexes carrageenan-depolymerized chitosan (C-DCh) and xanthandepolymerized chitosan (X-DCh) used for bulb coating improved plant productivity, allowing growers to speed up the production cycle in protected culture and to obtain higher quality flowers and bulbs of pineapple lily. Particularly strong biostimulant activity was shown for coatings containing derivatives of X-DCh. Bulb coatings in biostimulants seems a prospective, efficient, and environmentally friendly method of improving plant growth that can be recommended for sustainable production of ornamental plants. 
Author Contributions: Conceptualization, methodology, formal analysis and investigation, P.S.; writing, P.S., A.P. All authors have read and agreed to the published version of the manuscript.

Funding: This research received no external funding.

Institutional Review Board Statement: Not applicable.

Informed Consent Statement: Not applicable.

Data Availability Statement: Data sharing not applicable.

Conflicts of Interest: The authors declare no conflict of interest.

\section{References}

1. Malik, A.; Mor, V.S.; Tokas, J.; Punia, H.; Malik, S.; Malik, K.; Sangwan, S.; Tomar, S.; Singh, P.; Singh, N.; et al. Biostimulant-Treated Seedlings under Sustainable Agriculture: A Global Perspective Facing Climate Change. Agronomy 2021, 11, 14. [CrossRef]

2. Drobek, M.; Frąc, M.; Cybulska, J. Plant Biostimulants: Importance of the Quality and Yield of Horticultural Crops and the Improvement of Plant Tolerance to Abiotic Stress-A Review. Agronomy 2019, 9, 335. [CrossRef]

3. Rouphael, Y.; Colla, G. Biostimulants in Agriculture. Front. Plant Sci. 2020, 11, 40. [CrossRef]

4. Zulfiqar, F.; Casadesús, A.; Brockman, H.; Munné-Bosch, S. An Overview of Plant-Based Natural Biostimulants for Sustainable Horticulture with a Particular Focus on Moringa Leaf Extracts. Plant Sci. 2020, 295, 110194. [CrossRef] [PubMed]

5. Kocira, A.; Lamorska, J.; Kornas, R.; Nowosad, N.; Tomaszewska, M.; Leszczyńska, D.; Kozłowicz, K.; Tabor, S. Changes in Biochemistry and Yield in Response to Biostimulants Applied in Bean (Phaseolus vulgaris L.). Agronomy 2020, 10, 189. [CrossRef]

6. Elarroussia, H.; Elmernissia, N.; Benhimaa, R.; El Kadmiria, I.M.; Bendaou, N.; Smouni, A.; Wahbya, I. Microalgae polysaccharides a promising plant growth biostimulant. J. Algal Biomass Utln. 2016, 7, 55-63.

7. Yang, J.; Shen, Z.; Sun, Z.; Wang, P.; Jiang, X. Growth Stimulation Activity of Alginate-Derived Oligosaccharides with Different Molecular Weights and Mannuronate/Guluronate Ratio on Hordeum vulgare L. J. Plant Growth Regul. 2020, 1-10. [CrossRef]

8. Zhang, C.; Wang, W.; Zhao, X.; Wang, H.; Yin, H. Preparation of alginate oligosaccharides and their biological activities in plants: A review. Carbohydr. Res. 2020, 494, 108056. [CrossRef]

9. Salachna, P. Effects of Depolymerized Gellan with Different Molecular Weights on the Growth of Four Bedding Plant Species. Agronomy 2020, 10, 169. [CrossRef]

10. Shukla, P.S.; Borza, T.; Critchley, A.T.; Prithiviraj, B. Carrageenans from Red Seaweeds as Promoters of Growth and Elicitors of Defense Response in Plants. Front. Mar. Sci. 2016, 3, 81. [CrossRef]

11. Ahmed, K.B.M.; Khan, M.M.A.; Siddiqui, H.; Jahan, A. Chitosan and Its Oligosaccharides, a Promising Option for Sustainable Crop Production-a Review. Carbohydr. Polym. 2020, 227, 115331. [CrossRef] [PubMed]

12. Chakraborty, M.; Hasanuzzaman, M.; Rahman, M.; Khan, M.A.R.; Bhowmik, P.; Mahmud, N.U.; Tanveer, M.; Islam, T. Mechanism of Plant Growth Promotion and Disease Suppression by Chitosan Biopolymer. Agriculture 2020, 10, 624. [CrossRef]

13. Ohta, K.; Morishita, S.; Suda, K.; Kobayashi, N.; Hosoki, T. Effects of Chitosan Soil Mixture Treatment in the Seedling Stage on the Growth and Flowering of Several Ornamental Plants. J. Jpn. Soc. Hortic. Sci. 2004, 73, 66-68. [CrossRef]

14. Hernández-Hernández, H.; Juárez-Maldonado, A.; Benavides-Mendoza, A.; Ortega-Ortiz, H.; Cadenas-Pliego, G.; SánchezAspeytia, D.; González-Morales, S. Chitosan-PVA and Copper Nanoparticles Improve Growth and Overexpress the SOD and JA Genes in Tomato Plants under Salt Stress. Agronomy 2018, 8, 175. [CrossRef]

15. Malerba, M.; Cerana, R. Chitin- and Chitosan-Based Derivatives in Plant Protection against Biotic and Abiotic Stresses and in Recovery of Contaminated Soil and Water. Polysaccharides 2020, 1, 21-30. [CrossRef]

16. ALKahtani, M.D.F.; Attia, K.A.; Hafez, Y.M.; Khan, N.; Eid, A.M.; Ali, M.A.M.; Abdelaal, K.A.A. Chlorophyll Fluorescence Parameters and Antioxidant Defense System Can Display Salt Tolerance of Salt Acclimated Sweet Pepper Plants Treated with Chitosan and Plant Growth Promoting Rhizobacteria. Agronomy 2020, 10, 1180. [CrossRef]

17. Chen, Y.E.; Yuan, S.; Liu, H.M.; Chen, Z.Y.; Zhang, Y.H.; Zhang, H.Y. A combination of chitosan and chemical fertilizers improves growth and disease resistance in Begonia $\times$ hiemalis Fotsch. Hortic. Environ. Biotechnol. 2016, 57, 1-10. [CrossRef]

18. Elansary, H.O.; Abdel-Hamid, A.M.; Yessoufou, K.; Al-Mana, F.A.; El-Ansary, D.O.; Mahmoud, E.A.; Al-Yafrasi, M.A. Physiological and molecular characterization of water-stressed Chrysanthemum under robinin and chitosan treatment. Acta Physiol. Plant. 2020, 42, 31. [CrossRef]

19. Byczyńska, A. Chitosan improves growth and bulb yield of pineapple lily (Eucomis bicolor Baker) an ornamental and medicinal plant. World Sci. News 2018, 110, 159-171.

20. Salachna, P.; Zawadzińska, A. Effect of chitosan on plant growth, flowering and corms yield of potted freesia. J. Ecol. Eng. 2014, $15,97-102$.

21. Krupa-Małkiewicz, M.; Fornal, N. Application of chitosan in vitro to minimize the adverse effects of salinity in Petunia $\times$ atkinsiana D. Don. J. Ecol. Eng. 2018, 19, 143-149. [CrossRef]

22. Malerba, M.; Cerana, R. Recent advances of chitosan applications in plants. Polymers 2018, 10, 118. [CrossRef] [PubMed]

23. El-Miniawy, S.M.; Ragab, M.E.; Youssef, S.M.; Metwally, A.A. Response of strawberry plants to foliar spraying of chitosan. Res. J. Agric. Biol. Sci. 2013, 9, 366-372. 
24. Algam, S.A.E.; Xie, G.; Li, B.; Yu, S.; Su, T.; Larsen, J. Effects of Paenibacillus Strains and Chitosan on Plant Growth Promotion and Control of Ralstonia Wilt in Tomato. J. Plant Pathol. 2010, 92, 593-600.

25. Muhmed, S.A.; Nor, N.A.M.; Jaafar, J.; Ismail, A.F.; Othman, M.H.D.; Rahman, M.A.; Aziz, F.; Yusof, N. Emerging Chitosan and Cellulose Green Materials for Ion Exchange Membrane Fuel Cell: A Review. Energy Ecol. Environ. 2020, 5, 85-107. [CrossRef]

26. Szymańska, E.; Winnicka, K. Stability of chitosan-a challenge for pharmaceutical and biomedical applications. Mar. Drugs 2015, 13, 1819-1846. [CrossRef]

27. Bartkowiak, A.; Startek, L.; Salachna, P.; Zurawik, P. Method of Hydrogel Coating Formation on the Surface of Plant Organs. Pat. No PL 2008, 197101, 29.

28. Salachna, P.; Grzeszczuk, M.; Soból, M. Effects of Chitooligosaccharide Coating Combined with Selected Ionic Polymers on the Stimulation of Ornithogalum saundersiae Growth. Molecules 2017, 22, 1903. [CrossRef]

29. Startek, L.; Bartkowiak, A.; Salachna, P.; Kaminska, M.; Mazurkiewicz-Zapalowicz, K. The influence of new methods of corm coating on freesia growth, development and health. Acta Hortic. 2005, 673, 611-616. [CrossRef]

30. Vera, J.; Castro, J.; Contreras, R.A.; González, A.; Moenne, A. Oligo-carrageenans induce a long-term and broad-range protection against pathogens in tobacco plants (Var. Xanthi). Physiol. Mol. Plant Pathol. 2012, 79, 31-39. [CrossRef]

31. Abad, L.V.; Aurigue, F.B.; Relleve, L.S.; Montefalcon, D.R.V.; Lopez, G.E.P. Characterization of low molecular weight fragments from gamma irradiated $\mathrm{K}$-carrageenan used as plant growth promoter. Radiat. Phys. Chem. 2016, 118, 75-80. [CrossRef]

32. Vanegas, J.S.; Torres, G.R.; Campos, B.B. Characterization of a K-Carrageenan Hydrogel and Its Evaluation as a Coating Material for Fertilizers. J. Polym. Environ. 2019, 27, 774-783. [CrossRef]

33. Ahmad, B.; Jahan, A.; Sadiq, Y.; Shabbir, A.; Jaleel, H.; Khan, M.M.A. Radiation-Mediated Molecular Weight Reduction and Structural Modification in Carrageenan Potentiates Improved Photosynthesis and Secondary Metabolism in Peppermint (Mentha piperita L.). Int. J. Biol. Macromol. 2019, 124, 1069-1079. [CrossRef] [PubMed]

34. Akalin, G.O.; Pulat, M. Controlled Release Behavior of Zinc-Loaded Carboxymethyl Cellulose and Carrageenan Hydrogels and Their Effects on Wheatgrass Growth. J. Polym. Res. 2020, 27, 1-11. [CrossRef]

35. Saucedo, S.; González, A.; Gómez, M.; Contreras, R.A.; Laporte, D.; Sáez, C.A.; Zúñiga, G.; Moenne, A. Oligo-Carrageenan Kappa Increases Glucose, Trehalose and TOR-P and Subsequently Stimulates the Expression of Genes Involved in Photosynthesis, and Basal and Secondary Metabolisms in Eucalyptus globulus. BMC Plant Biol. 2019, 19, 1-13. [CrossRef]

36. San, P.T.; Khanh, C.M.; Khanh, H.H.N.; Khoa, T.A.; Hoang, N.; Nhung, L.T.; Trinh, N.T.K.; Nguyen, T.-D. k-Oligocarrageenan Promoting Growth of Hybrid Maize: Influence of Molecular Weight. Molecules 2020, 25, 3825. [CrossRef]

37. Kumar, A.; Rao, K.M.; Han, S.S. Application of xanthan gum as polysaccharide in tissue engineering: A review. Carbohydr. Polym. 2018, 180, 128-144. [CrossRef]

38. Luiz, C.; Schauffler, G.P.; Lemos-Blainski, J.M.; Rosa, D.J.; Di Piero, R.M. Mechanisms of action of aloe polysaccharides and xanthan gum for control of black rot in cauliflower. Sci. Hortic. 2016, 200, 170-177. [CrossRef]

39. Van Binh, N.; Diep, T.B.; Sang, H.D.; Thao, H.P.; Thom, N.T.; Quynh, T.M. Low Molecular Weight Xanthan Prepared by Gamma Irradiation and Its Effects on Development of Seedlings. RAD Conf. Proc. 2016, 1, 95-98. [CrossRef]

40. Jeong, H.; Jang, H.Y.; Ahn, S.J.; Kim, E. $\beta$-Glucan-and Xanthan Gum-Based Biopolymer Stimulated the Growth of Dominant Plant Species in the Korean Riverbanks. Ecol. Resilient Infrastruct. 2019, 6, 163-170.

41. Jain, R.; Babbar, S.B. Xanthan gum: An economical substitute for agar in plant tissue culture media. Plant Cell Rep. 2006, 25, 81-84. [CrossRef] [PubMed]

42. Carlson, A.S.; Dole, J.M. Postharvest handling recommendations for cut pineapple lily. HortTechnology 2014, 24, 731-735. [CrossRef]

43. Carlson, A.S.; Dole, J.M. Determining Optimal Bulb Storage and Production Methods for Successful Forcing of Cut Pineapple Lily. HortTechnology 2015, 25, 608-616. [CrossRef]

44. Salachna, P.; Grzeszczuk, M.; Meller, E.; Soból, M. Oligo-Alginate with Low Molecular Mass Improves Growth and Physiological Activity of Eucomis autumnalis under Salinity Stress. Molecules 2018, 23, 812. [CrossRef]

45. Masondo, N.A.; Finnie, J.F.; Van Staden, J. Pharmacological potential and conservation prospect of the genus Eucomis (Hyacinthaceae) endemic to southern Africa. J. Ethnopharmacol. 2014, 151, 44-53. [CrossRef]

46. Salachna, P.; Grzeszczuk, M.; Wilas, J. Total phenolic content, photosynthetic pigment concentration and antioxidant activity of leaves and bulbs of selected Eucomis L'Hér. taxa. Fresen. Environ. Bull. 2015, 24, 4220-4225.

47. Salachna, P.; Mizielińska, M.; Soból, M. Exopolysaccharide Gellan Gum and Derived Oligo-Gellan Enhance Growth and Antimicrobial Activity in Eucomis Plants. Polymers 2018, 10, 242. [CrossRef]

48. Salachna, P.; Zawadzińska, A. Effect of nitric oxide on growth, flowering and bulb yield of Eucomis autumnalis. Acta Hortic. 2017, 1201, 635-640.

49. Salachna, P.; Zawadzińska, A. Comparison of morphological traits and mineral content in Eucomis autumnalis (Mill.) Chitt. plants obtained from bulbs treated with fungicides and coated with natural polysaccharides. J. Ecol. Eng. 2015, 16, 126-142. [CrossRef]

50. Ostrowska, A.; Gawliński, S.; Szczubiałka, Z. Methods for Analyzing and Assessing the Properties of Soil and Plants; Instytut Ochrony Środowiska: Warsaw, Poland, 1991; pp. 1-333.

51. Salachna, P.; Mikiciuk, M.; Zawadzińska, A.; Piechocki, R.; Ptak, P.; Mikiciuk, G.; Pietrak, A.; Łopusiewicz, Ł. Changes in Growth and Physiological Parameters of $\times$ Amarine Following an Exogenous Application of Gibberellic Acid and Methyl Jasmonate. Agronomy 2020, 10, 980. [CrossRef] 
52. AOAC Official Methods of Analysis of the Association of Official Analytical Chemists; Association of Official Analytical Chemists: Washington, DC, USA, 1990.

53. Wojdyło, A.; Oszmiański, J.; Czemerys, R. Antioxidant activity and phenolic compounds in 32 selected herbs. Food Chem. 2007, 105, 940-949. [CrossRef]

54. Yen, G.C.; Chen, H.Y. Antioxidant activity of various tea extracts in relation to their antimutagenicity. J. Agric. Food Chem. 1995, 43, 27-32. [CrossRef]

55. Rossi, M.; Giussani, E.; Morelli, R.; Scalzo, R.; Nani, R.C.; Torreggiani, D. Effect of fruit blanching on phenolics and radical scavenging activity of highbush blueberry juice. Food Res. Int. 2003, 36, 999-1005. [CrossRef]

56. Ma, Y. Seed coating with beneficial microorganisms for precision agriculture. Biotechnol. Adv. 2019, 37, 107423. [CrossRef] [PubMed]

57. Antoniazzi, N.; Deschamps, C.; Bach, E.E. Effect of xanthan gum and allicin as elicitors against Bipolaris sorokiniana on barley in field experiments. J. Plant Dis. Prot. 2008, 115, 104-107. [CrossRef]

58. Rademacher, W. Plant growth regulators: Backgrounds and uses in plant production. J. Plant Growth Regul. 2015, 34, 845-872. [CrossRef]

59. Rouphael, Y.; Colla, G. Synergistic biostimulatory action: Designing the next generation of plant biostimulants for sustainable agriculture. Front. Plant Sci. 2018, 9, 1655. [CrossRef]

60. Bot, J.L.; Benard, C.; Robin, C.; Bourgaud, F.; Adamowicz, S. The 'trade-off' between synthesis of primary and secondary compounds in young tomato leaves is altered by nitrate nutrition: Experimental evidence and model consistency. J. Exp. Bot. 2009, 60, 4301-4314. [CrossRef]

61. Caretto, S.; Linsalata, V.; Colella, G.; Mita, G.; Lattanzio, V. Carbon Fluxes between Primary Metabolism and Phenolic Pathway in Plant Tissues under Stress. Int. J. Mol. Sci. 2015, 16, 26378-26394. [CrossRef]

62. Ibrahim, M.H.; Jaafar, H.Z.E.; Rahmat, A.; Rahman, Z.A. Effects of Nitrogen Fertilization on Synthesis of Primary and Secondary Metabolites in Three Varieties of Kacip Fatimah (Labisia pumila Blume). Int. J. Mol. Sci. 2011, 12, 5238-5254. [CrossRef] 